\title{
Comparison of two WHO partographs: a one year randomized controlled trial
}

\author{
İki DSÖ partografının karşılaştırlması: Bir yıllık randomize kontrollü çalışma
}

\author{
Swamy Mallaiah Kenchaveeriah, Kamal Prakash Patil, Tania Gurudeep Singh \\ Department of Obstetrics and Gynaecology, Kle University, Jawaharlal Nehru Medical College, Belgaum, Karnataka, India
}

\section{Abstract}

Objective: To compare two World Health Organization (WHO) partographs - a composite partograph including the latent phase with a simplified one without the latent phase in women with uncomplicated pregnancy.

Material and Methods: This was a randomized controlled trial conducted at a tertiary hospital at Belgaum, India. 743 women with term, singleton, vertex gestation, in spontaneous labor were included in the study over a period of one year. Either of the partographs was used on laboring women. The following outcomes were compared: labor crossing the alert and action line, augmentation of labor, rate of cesarean section, perinatal outcome, user friendliness and maternal complications. Statistical analysis was done using Chi-square test.

Results: Labor values crossed the alert and action lines significantly more often when composite partograph was used $(p<0.001)$ in each, with increased number of augmentations $(p<0.001)$. The number of vaginal deliveries were high $(\mathrm{p}<0.005)$ in the simplified group. There was no significant difference in the rate of cesarean deliveries due to non progress of labor in both groups $(\mathrm{p}=0.68)$. NICU admissions were higher in the composite group ( $\mathrm{p}=0.035)$. Most resident doctors (93\%) experienced difficulty with the composite partograph, but no resident doctor reported difficulty with the simplified partograph. The mean SD user friendliness score was lower for the composite partograph $(2.87 \pm 1.86$ vs $10.67 \pm 1.61 ; \mathrm{p}<0.005)$.

Conclusion: The WHO simplified partograph is easier to use and is a better option for both the laboring women and the user, when compared to composite partograph.

(J Turkish-German Gynecol Assoc 2011; 12: 31-4)

Key words: World Health Organization, partograph, latent phase, action line, alert line, user friendliness

Received: 18 October, 2010

Accepted: 23 February, 2011
Özet

Amaç: İki Dünya Sağlık Örgütü (DSÖ) partografını karşılaştırmak komplike olmamış gebeliği olan kadınlarda latent fazı içeren bileşik bir partograf ile latent fazı olmayan basit bir partograf.

Gereç ve Yöntemler: Bu çalışma Belgaum, Hindistan'da üçüncü basamak bir hastanede yapılmış randomize kontrollü bir çalışmadır. Çalışmaya bir yıllık süre içinde termde, tekil gebeliği, baş gelişi ve spontan doğum sancısı olan 743 kadın dahil edildi. Doğum sancısı olan kadınlarda partograflardan biri kullanıldı. Aşağıdaki sonuçlar karşılaştırıldı: alarm ve eylem çizgisini geçen doğum sancısı, suni sancı, sezaryen doğum oranı, perinatal sonuç, kullanım kolaylığı ve maternal komplikasyonlar. İstatistiksel analiz Ki-kare testi kullanılarak yapıldı.

Bulgular: Bileşik partograf kullanıldığında doğum sancısı değerleri alarm ve eylem çizgilerini daha sıklıkla geçti $(p<0.001)$ ve hepsinde suni sancı sayısı arttı $(\mathrm{p}<0.001)$. Basitleştirilmiş grupta vajinal doğum sayısı yüksekti $(p<0.005)$. Her iki grup arasında doğumun ilerlememesi nedeniyle yapılan sezaryen doğum oranı açısından anlamlı farklılık yoktu ( $p=0.68)$. YYBÜ'ne yatışlar bileşik grupta daha fazlaydı $(p=0.035)$. Asistan doktorların çoğu (\%93) bileşik partograf ile zorluk yaşadı ancak asistan doktorların hiçbiri basitleştirilmiş partograf ile bir zorluk bildirmedi. Ortalama SS kullanım kolaylı̆̆ı skoru bileşik partograf için daha düşüktü $(2.87 \pm 1.86$ 'ya karşıllı $10.67 \pm 1.61 ; \mathrm{p}<0.005)$. Sonuç: DSÖ basitleştirilmiş partografının kullanımı daha kolaydır ve bileşik partografa kıyasla hem doğum sancısındaki kadın hem de kullanıcı için daha iyi bir seçenektir.

(J Turkish-German Gynecol Assoc 2011; 12: 31-4)

Anahtar kelimeler: Dünya Sağlık Örgütü, partograf, geç faz, eylem çizgisi, alarm çizgisi, kullanım kolaylığı

Geliş Tarihi: 18 Ekim 2010

Kabul Tarihi: 23 Şubat 2011

\section{Introduction}

Partograph is a Greek word meaning "Labor Curve"(1). It is a graphic recording of progress of labor and salient features in the mother and fetus. It detects labor that is not progressing normally, indicates when augmentation of labor is appropriate and recognizes cephalo-pelvic disproportion long before labor becomes "obstructed". It serves as an early warning system and assists in early decision making on transfer, augmentation and termination of labour (2).
Obstructed labor remains an important cause of not only maternal death but also short and long term disability. India has a high maternal mortality of about $300-500$ per 100,000 births, of which $10 \%$ are due to obstructed labor (3-5). To reduce the maternal mortality rate, the problem of obstructed labor will need to be addressed effectively. Improved outcome after obstructed labor requires early detection of abnormal progress of labor, which can be easily identified with the use of a partograph.

The development of a partograph started in 1970, when Philpott's partograph was developed from the original cervi- 
cograph of Friedman (6). But its use was only rigorously evaluated 20 years after its introduction (7). It was only in 1994 that WHO devised the composite partograph. It included a latent phase of 8 hours. It was an adaptation of the one formulated and described by Philpott and colleagues (8).

Since the first publications on cervicography, the issue of the latent phase has been controversial, (9) as there is always a risk of inappropriate interventions if undue attention is paid to the latent phase (10). Subsequently, in 2000 the WHO produced the modified partograph where the latent phase was removed, to make it simpler and easier to use (11).

In India, the use of the partograph has not been incorporated and practiced widely, even at the tertiary level. There is very limited data available in Indian literature, comparing the two WHO partographs. Comparison of the two WHO partographs (a composite one with a latent phase and a simplified one without a latent phase) can tell which partograph is associated with better maternal and perinatal outcomes and is more user friendly. Hence, the present study was undertaken to highlight the efficacy of either WHO partograph, so that the partograph becomes a routine practice in our setup.

\section{Materials and Methods}

This randomized controlled trial was conducted at a tertiary care hospital, Belgaum, India, from November 2008 to October 2009, after having obtained clearance from the institutional ethical committee. All women with uncomplicated, singleton, term, vertex gestations, in spontaneous labor and those willing to participate after informed and written consent, were included in the study.

The sample size was calculated using the formula $\mathrm{N}=(\mathrm{Z} \alpha+\mathrm{Z} \beta)^{2}$ x $2 p(1-p) \div d^{2}$,taking the level of significance as $5 \%, Z \alpha=1.96$ and power of the test as $80 \%, Z \beta=0.84 . p=0.113$. A sample size of 65 in each group was calculated. However, since the study was conducted over a period of one year, all women meeting the inclusion criteria were included. Hence a total of 743 women were studied. Either partograph was used according to computer generated random number table.

Exclusion criteria included women with short stature (<140cm.), antepartum haemorrhage, severe preeclampsia / eclampsia, anaemia (haemoglobin <10g), malpresentations, multiple pregnancy, previous caesarean section, preterm labor, fetal distress and intrauterine death. The partograph was started after establishment of true labor defined as the presence of uterine contractions with show with or without cervical changes. A total of 31 resident doctors working in 12 hour shifts at this teaching hospital were instructed to use both the partographs. The plotting of the composite partograph was started as soon as the woman was in labor. In the simplified partograph, the plotting of the partograph was started with $\geq 4 \mathrm{~cm}$ of cervical dilatation. Labor was monitored until delivery. The outcome was reported at the bottom of each partograph. The outcomes noted were labors crossing the alert and action line, augmentation of labor, rate of cesarean section, perinatal outcome, user friendliness and maternal complications.
Analysis was made using Chi-square test and $\mathrm{p}$ value less than 0.05 was considered significant.

Non progress of labour was defined as labour crossing the alert line after four hours. Cephalo pelvic disproportion (CPD) was defined as disproportion between the fetal head and the pelvis in active labour (non descent of the head at $4 \mathrm{~cm}$ of cervical dilatation after rupture of membranes). Failed ventouse was defined when vaginal delivery did not occur after 3 pop offs. Prolonged labour was defined when the woman was in labour for more than twelve hours in the active phase.

\section{Results}

The total numbers of deliveries were 3110 , of which 743 women fulfilled the inclusion criteria and were enrolled in the study. Out of 350 patients in thecomposite group, 192 were primigravidae and 158 were multigravidae. 204 primgravida and 189multigravida were enrolled in the simplified partograph group as shown in Table 1.

In this study labor values crossed the alert and action lines significantly more often when the composite partograph was used $(p<0.001)$ each with an increased number of augmentations $(p<0.001)$. The number of vaginal deliveries were high $(\mathrm{p}<0.005)$ in the simplified group. There was no significant difference in rate of cesarean deliveries due to non progress of labor in the two groups $(\mathrm{p}=0.68)$.

Labor crossed the alert line in 98 cases monitored by the composite partograph and 55 cases monitored with the simplified partograph. Labor crossing the action line was found in 40 patients for whom the composite partograph was plotted whereas in patients monitored with the simplified partograph, labor crossed the action line in 8 cases $(\mathrm{p}<0.05)$ as shown in Table 2.

Augmentation of labor was required in 126 cases who were randomized to the composite partograph and in 65 patients subjected to the simplified partograph $(\mathrm{p}<0.05)$. One important association which was found in the current study was that augmentation was higher in patients in whom labor had crossed the alert and action lines. 265 women in the composite partograph group and 351 women in the simplified group delivered vaginally $(p<0.05)$. Out of these, almost the same number of patients, 24 in the composite group and 26 in the simplified group, had instrumental delivery.

Of the patients randomized to the composite partograph, 83 underwent cesarean section. In patients with the simplified par-

Table 1. Patient characteristics

\begin{tabular}{|l|c|c|c|}
\hline Variable & $\begin{array}{c}\text { Composite } \\
\mathbf{n}=\mathbf{3 5 0}\end{array}$ & $\begin{array}{c}\text { Simplified } \\
\mathbf{n}=\mathbf{3 9 3}\end{array}$ & $\begin{array}{c}\mathbf{P} \\
\text { value }\end{array}$ \\
\hline Age & $24.60 \pm 3.46$ & $24.66 \pm 3.57$ & $\begin{array}{c}\mathrm{t}=0.05 \\
\mathrm{DF}=98, \mathrm{p}=0.932\end{array}$ \\
\hline BMI & $25.64 \pm 3.27$ & $24.99 \pm 3.29$ & $\begin{array}{c}\mathrm{t}=1.401 \\
\mathrm{DF}=98, \mathrm{p}=0.164\end{array}$ \\
\hline $\begin{array}{l}\text { Primigravida } \\
\text { Multigravida }\end{array}$ & $152(54.8 \%)$ & $204(51.90 \%)$ & $\mathrm{x}^{2}=0.646$ \\
$\mathrm{DF}=1, \mathrm{p}=0.421$
\end{tabular}


tograph, cesarean section was performed in 39 cases $(\mathrm{p}<0.05)$ as shown in Table 2. The indication for cesarean section in the majority of patients in both groups was fetal distress (Table 3). Only $3.41 \%$ in thecomposite and $2.54 \%$ in the simplified group underwent cesarean section for non progress of labor. There were no cases of obstructed or prolonged labor in either of the groups. Maternal complications such as postpartum hemorrhage was observed in 1 case in each partograph group respectively. No woman suffered from puerperal sepsis.

NICU admissions were statistically significant in the composite partograph group $68(19.4 \%)$ as compared to $35(8.90 \%)$ in the

Table 2. Comparison of labor outcomes and user satisfaction

\begin{tabular}{|c|c|c|c|c|c|}
\hline Variable & $\begin{array}{c}\text { Composite } \\
(n=350)\end{array}$ & $\%$ & $\begin{array}{c}\text { Simplified } \\
(n=393)\end{array}$ & $\%$ & $\begin{array}{c}P \\
\text { value }\end{array}$ \\
\hline $\begin{array}{l}\text { Labour crossing } \\
\text { the alert line }\end{array}$ & 98 & & 55 & & \\
\hline Primiparous & 63 & $18 \%$ & 33 & $8.39 \%$ & 0.0001 \\
\hline Multiparous & 35 & $10 \%$ & 22 & $5.59 \%$ & 0.0080 \\
\hline $\begin{array}{l}\text { Labour crossing } \\
\text { the alert line }\end{array}$ & 40 & & 8 & & \\
\hline Primiparous & 28 & $8 \%$ & 7 & $1.78 \%$ & 0.005 \\
\hline Multiparous & 12 & $3.42 \%$ & 1 & $5.59 \%$ & 0.005 \\
\hline $\begin{array}{l}\text { Augmentation of } \\
\text { labour }\end{array}$ & 126 & & 65 & & \\
\hline Primiparous & 76 & $21.7 \%$ & 37 & $9.41 \%$ & $<0.0001$ \\
\hline Multiparous & 50 & $14.2 \%$ & 28 & $7.12 \%$ & 0.0004 \\
\hline Vaginal Delivery & 265 & & 351 & & \\
\hline Primiparous & 130 & $37.14 \%$ & 170 & $43.2 \%$ & 0.0055 \\
\hline Multiparous & 135 & $38.57 \%$ & 181 & $46.05 \%$ & 0.0007 \\
\hline $\begin{array}{l}\text { Instrumental } \\
\text { delivery }\end{array}$ & 24 & & 26 & & \\
\hline Primiparous & 23 & $6.57 \%$ & 23 & $5.85 \%$ & 0.98 \\
\hline Multiparous & 1 & $0.28 \%$ & 3 & $0.76 \%$ & 0.74 \\
\hline Cesarean Section & 83 & & 39 & & \\
\hline Primiparous & 62 & $17.71 \%$ & 33 & $8.39 \%$ & 0.0010 \\
\hline Multiparous & 21 & $6.00 \%$ & 6 & $1.52 \%$ & 0.0007 \\
\hline Admission to NICU & 69 & & 42 & & \\
\hline Primiparous & 39 & $11.14 \%$ & 23 & $5.85 \%$ & 0.040 \\
\hline Multiparous & 30 & $8.57 \%$ & 19 & $4.83 \%$ & 0.028 \\
\hline $\begin{array}{l}\text { Apgar score } \\
<7 \text { at } 5\end{array}$ & 4 & & 6 & & \\
\hline Primiparous & 3 & $0.85 \%$ & 5 & $1.27 \%$ & 0.67 \\
\hline Multiparous & 1 & $0.28 \%$ & 1 & $0.25 \%$ & 0.55 \\
\hline $\begin{array}{l}\text { User friendliness } \\
\text { score }\end{array}$ & $2.87 \pm 1.86$ & & $10.76 \pm 1.61$ & $<0.005$ & \\
\hline $\begin{array}{l}\text { Difficulty in using } \\
\text { the partograph }\end{array}$ & $93 \%$ & & $0 \%$ & & \\
\hline
\end{tabular}

Table 3. Indications for Cesarean Section

\begin{tabular}{|l|c|c|c|c|c|}
\hline $\begin{array}{l}\text { Indications for } \\
\text { C.S. }\end{array}$ & $\begin{array}{c}\text { Composite } \\
(\mathbf{n = 3 5 0 )}\end{array}$ & $\mathbf{\%}$ & $\begin{array}{c}\text { Simplified } \\
(\mathbf{n = 3 9 3 )}\end{array}$ & $\mathbf{\%}$ & $\begin{array}{c}\mathbf{P} \\
\text { value }\end{array}$ \\
\hline Fetal distress & 65 & $18.6 \%$ & 15 & $3.82 \%$ & 0.001 \\
\hline CPD & 1 & $0.30 \%$ & 3 & $0.76 \%$ & 0.72 \\
\hline $\begin{array}{l}\text { Non progress of } \\
\text { labor }\end{array}$ & 12 & $3.41 \%$ & 10 & $2.54 \%$ & 0.68 \\
\hline $\begin{array}{l}\text { Deep transverse } \\
\text { arrest }\end{array}$ & 3 & $0.86 \%$ & 5 & $1.30 \%$ & 0.51 \\
\hline Failed ventouse & 2 & $0.57 \%$ & 5 & $1.30 \%$ & 0.43 \\
\hline Obstructed labor & 0 & $0 \%$ & 0 & $0 \%$ & 0.0 \\
\hline Total & 83 & $23.7 \%$ & 38 & $9.7 \%$ & 0.001 \\
\hline
\end{tabular}

simplified group $(\mathrm{p}<0.05)$ as depicted in Table 4 . However it was not related directly to monitoring of labor.

Resident doctors scored the two partographs for each of the following categories: teachability, overall usefulness, interpretation and overall rating. The mean (S.D.) user friendliness score was lower for the composite partograph $(2.87 \pm 1.86$ vs $10.67 \pm 1.61 ; \mathrm{p}<0.005)$. Most of them (93\%) experienced difficulty with the composite partograph, but none reported difficulty while plotting the simplified partograph, as shown in Table 2.

\section{Discussion}

Maternal mortality reduction is one of India's developmental priorities. One of the challenges in this respect is the quality of obstetric practice, comma should not be there before and failure to use the partograph in the monitoring of labor reflects inadequate process of care. The WHO partographs are the best known partographs in low resource settings (11). In India, the partograph is not widely incorporated in our day to day practice as there is a lack of awareness and very few reports available comparing the two WHO partographs. The present study was conducted at a University teaching hospital to compare the two WHO partographs and its user friendliness.

In the present study, labor crossing the alert line was found in $28.2 \%$ of patients in the composite partograph group and $13.7 \%$ of patients in the simplified partograph group $(p=0.0001)$. Similar study done at Vellore, India reports $17.7 \%$ and $15.1 \%$ in the two groups respectively (12). A study done in Pakistan showed $11.6 \%$ of labors to cross the alert line in the simplified partograph group (13). 23.6\% of patients crossed the alert line when the composite partograph was plotted in a study conducted in Medan, Indonesia (14).

Labor crossing the action line was observed in 10.8\% and 1.96\% parturients in the composite and simplified group respectively $(p=0.005)$. Almost similar observations were made by the study done at Vellore where labor had crossed the action line in 7.0\% in the composite group as compared to $1.0 \%$ in the simplified group (12). Action line was crossed in 38\% of cases in the composite partograph group at a study done in Liverpool (15).

One important association which we found in the current study was that augmentation was higher in patients in whom labor 
Table 4. Indication for admission to NICU

\begin{tabular}{|l|c|c|c|c|c|}
\hline Indications for admission & Composite (n=350) & $\mathbf{\%}$ & Simplified (n=393) & \% & P value \\
\hline Hyperbilirubinaemia & 29 & $8.2 \%$ & 14 & $3.56 \%$ & $<0.05$ \\
\hline Meconium aspiration syndrome & 8 & $2.2 \%$ & 3 & $0.76 \%$ & 0.55 \\
\hline Sepsis & 5 & $1.4 \%$ & 4 & $1.01 \%$ & 0.64 \\
\hline Asphyxia & 1 & $0.28 \%$ & 3 & $0.76 \%$ & 0.57 \\
\hline Low birth weight & 14 & $4 \%$ & 6 & $1.52 \%$ & $<0.05$ \\
\hline Others & 11 & $3.14 \%$ & 5 & $1.27 \%$ & 0.05 \\
\hline Total & 68 & $19.4 \%$ & 35 & $8.90 \%$ & 0.035 \\
\hline
\end{tabular}

had crossed the alert and action lines. Similar results were noted in a study done in Belgium where $26 \%$ had crossed the action line even after augmentation, when the composite partograph was used (16). The present study was again in accordance to a study done in Leeds, UK where they had intervened actively when the latent phase of the partograph was used (10). The success rate in terms of vaginal delivery in our study was $76.08 \%$ in the composite group and $89.9 \%$ in the simplified partograph group.A study done in Calcutta had $80.6 \%$ of cases who delivered vaginally in the composite group and $82.7 \%$ in the simplified group (1).

$23.9 \%$ and $10.08 \%$ in thecomposite and simplified groups respectively underwent cesarean section $(p=0.001)$. A study from Calcutta had similar results, where it was $10 \%$ and $8.9 \%$ in each (1). Published literature from Dublin, Ireland, highlights $5.4 \%$ of patients undergoing cesarean section in the composite partograph group, (17) but a study from Vellore showed only $8.8 \%$ and $2.35 \%$ of parturients undergoing cesarean section (12).

Another aspect of the study was observation of the neonates of these parturients. We detected no statistically significant difference in the number of infants with Apgar score $<7$ at 5 minutes in both the groups where it was $1.24 \%$ and $1.68 \%(p=0.678$ and $\mathrm{p}=0.555$ in primigravidas and multigravidas respectively).The study at Vellore had similar results of $2 \%$ in each group (12). The Liverpool study had $1.6 \%$ of cases in the composite group (15). However, results varied with the study in Indonesia, where an Apgar score of $<7$ at 5 minutes was observed in $7.0 \%$ of cases in the composite group (14).

$19.8 \%$ and $10.92 \%$ of the babies born to mothers monitored by composite and simplified partographs respectively were admitted to NICU $(\mathrm{p}=0.035)$.

The majority of admissions were due to hyperbilirubinaemia and low birth weight. Although the difference between the two groups was statistically significant, it was not related directly to monitoring of labor with the composite partograph. Meconium aspiration syndrome, sepsis and birth asphyxia were other important causes. The Vellore study had similarities with our results, where the admissions to NICU care were $20 \%$ in the composite group and $16 \%$ in the simplified group (12).

In the present study, we observed that labor can be managed without the latent phase being plotted on the partograph. However, a labor management protocol for the latent phase should be instituted with clear guidelines. The interventions were higher when the latent phase was included, with a larger number of cesarean sections. The residents had difficulties in transferring from latent to active phase when the composite partograph was used. Our study favors the use of the WHO simplified partograph, which should become routine practice in monitoring labor for better maternal and perinatal outcome.

\section{Conflict of interest}

None declared.

\section{References}

1. Alauddin Md, Runa Bal, Arunangsu De, Parthajit Mandal, Mayoukh Chakraborty. Monitoring of labor with WHO modified partogram - A study report. NJOG 2008; 3: 8-11.

2. Fatusi AO, Makinde ON, Adeyemi AB, Orji EO, Onwudiegwu U. Evaluation of health workers training in use of the partogram. International Journal of gynecology and obstetrics 2008; 100: 41-4.

3. UNICEF: India Statistics

4. WHO: Maternal Mortality in 2000: Estimates Developed by WHO, UNICEF, and UNFPA.

5. Krupp K, Madhivanan P. Leveraging human capital to reduce maternal mortality in India: enhanced public health system or public- private partnership? Bio Med Central 2009; 7: 18.

6. Philpott R.H. Graphic records in labour. British Medical Journal 1972; 4: 163-5. [CrossRef]

7. World Health Organization. Maternal Health and Safe Motherhood Programme. World Health Organization partograph in management of labour. Lancet 1994; 343: 1399-404.

8. Neilson JP, Lavender T, Quenby S and Wray S. Obstructed labour. British Medical Bulletin 2003; 67: 191-204. [CrossRef]

9. van Bogaert LJ. The partogram. SAMJ 2003; 93: 830-3.

10. Cartmill RSV, Thornton JG. Effect of presentation of partogram information on obstetric decision making. Lancet 1992; 339: 1520-2. [CrossRef]

11. Matthews M. The partograph for the prevention of obstructed labor. Clinical Obstetrics and Gynecology 2009; 52: 256-69. [CrossRef]

12. Mathews J.E, Rajaratnam A, George A, Mathai M, Comparison of the two WHO partographs.Internationsl Journal of Gyaecology and Obstetrics 2007; 96: 147-50. [CrossRef]

13. Javed I, Bhutta S, Tabassum S. Role of partogram in preventing prolonged labour. Journal of Pakistan Medical Association 2007; 57: 408.

14. Fahdhy M, Chongsuvivatwong M. Evaluation of World Health organization partograph. Midwifery implementation by midwives for maternity home birth in Medan, Indonesia.Midwifery,2005; 21: 301-10. [CrossRef]

15. Lavender T, Alfirevic Z, Walkinshaw S. Partogram action line study: a randomized trial.RCOG 1998; 105: 976-80.

16. Dujardin B, De Schampheleire I et al. Value of the alert and action lines on the partogram. Lancet 1992; 25: 340: 240.

17. Impey L, Hobson J, O'herlihy C. Graphic analysis of actively managed labour: Prospective study in 500 consecutive nulliparous women in spontaneous labour. AJOG 2000; 183: 438- 43. [CrossRef] 